\title{
RELATIONSHIP BETWEEN ORGANIZATIONAL COMMUNICATION AND CREATIVITY: HOW IT ADVANCES IN RIGID STRUCTURES?
}

\author{
Rasa SMALIUKIENE $\dot{1}^{1, *}$, Antanas SURVILAS $^{2}$ \\ ${ }^{1}$ Vilnius Gediminas Technical University, Faculty of Creative Industries, \\ Department of Creative Communication, Traku g. 1, LT-01132 Vilnius, Lithuania \\ ${ }^{2}$ General Jonas Žemaitis Military Academy of Lithuania, Department of Strategic Management, \\ Šilo g. 5A, LT-10322 Vilnius Lithuania
}

Received 18 July 2018; accepted 27 September 2018

\begin{abstract}
A growing number of research papers present systematic investigations of creative behaviour in complex social systems rather than emphasise individual creativity; however, surprisingly little has been done to investigate communication at the workplace in which such creativity is revealed. It should also be noted that communication that takes place in rigid organizational structures and simultaneously activates creativity is phenomenon that has not yet been analysed. This article discusses organizational communication and its impact on creativity by analysing corporate, team and leadership communication levels, taking military as a research context. Thus, this research addresses the following two questions: (i) how is organizational communication related to creativity? and (ii) how communication on different levels contribute to organizational creativity in rigid structures? To answer these questions a theoretical multi-factor model was created and empirically tested using AMOS Software. On the basis of empirical findings, a three-level model of organizational communication for creativity in rigid organizational structures was proposed.
\end{abstract}

Keywords: corporate communication, leadership communication, military, organizational communication, organizational creativity, team communication.

\section{Introduction}

Communication is the key factor in shaping social context (Duncan, 2002) and developing intangible organizational assets such as creativity. Communication in organizations is used to link goals and strategies with everyday activities and to utilise its social capital. Unlike the organizational structure that creates gaps among people, organizational communication resolves organizational complications and facilitates the dissemination of ideas (Sadia, Mohd Salleh, Abdul Kadir, \& Sanif, 2016). According to Xiaomeng Zhang and Kathryn M. Bartol (2010), organizations can accelerate their performance by attracting and exploiting creative employees; however, this often does not happen due to communication inefficiency (Chen \&

${ }^{\star}$ Corresponding author. E-mail: rasa.smaliukiene@vgtu.lt 
Agrawal, 2017). Even though a large body of literature suggests that communication is a prerequisite for organizational creativity (e.g. Negus \& Pickering, 2004; Boies, Fiset, \& Gill, 2015), the understanding of mediational pathways between these two remains limited. Thus, this paper fills the gap by combining two separate streams in organizational research where the first reflects the paradigm of the organizational behaviour theory and highlights the importance of organizational communication on corporate, team and individual levels (Saintilan \& Schreiber, 2017), and the second one reveals a unique capacity of an organization and represents organizational creativity as the first step in innovation management (Anderson, Potočnik, \& Zhou, 2014).

The research addresses the following two questions: (i) how is organizational communication related to creativity? and (ii) how communication on different levels contribute to organizational creativity in rigid structures? This article discusses organizational communication and its impact on creativity by analysing corporate, team and leadership communication, taking military as a research context. The military context was chosen as a typical for rigid structure with "highly centralized and hierarchical command" (Vego, 2013) where simultaneously a unique level of creativity is encouraged.

The paper proceeds as follows. Firstly, we review the existing literature concerning organizational communication and organizational creativity and develop theoretical framework for the structural interdependence of these two factors. We continue by outlining our research instrument and theoretical multi-factor model. The model was empirically tested using AMOS Software. Finally, on the basis of empirical findings, we propose a three-level model of organizational communication for creativity in rigid organizational structures.

\section{Conceptual review}

Former studies on organizational creativity repeatedly cite the definition provided by Richard W. Woodman, John E. Sawyer and Ricky W. Griffin (1993, p. 293) where organizational creativity is defined as "the creation of a valuable, useful new product, service, idea, procedure, or process by individuals working together in a complex social system". The complexity is due to communicative interactions that takes place at different organizational levels. Although communication is constructive in an organization, it cannot be considered only as means. According to François Cooren, Timothy Kuhn, Joep P. Cornelissen and Timothy Clark (2011, p. 1150), organizational communication "cannot be merely the vehicle for the expression of pre-existing 'realities"', it is rather a tool used to create and maintain the organization. Accordingly, while examining the importance of communication for organizational creativity, it should be perceived as the context rather than a means. When emphasizing the importance of organizational communication, it is often suggested to imagine a situation where an organization does not have effective communication, and then no organization can grow or even survive (Ruler \& Lange, 2003; Sadia et al., 2016). Thus, effective organizational communication is important where creative solutions are required.

A focus on scarce literature that links organizational creativity and communication discloses three main paradigms how this phenomenon is analysed. The first paradigm represents research papers with the primary focus on corporate internal communication as a supporting 
factor for creativity. Corporate internal communication in this context is perceived as communication between the organization and its employees that helps to engage employees' intellectual and creative thinking (Malhotra \& Ackfeldt, 2016). Team communication represents the second paradigm where creativity is perceived as a competitive advantage and an integral part of innovation process. Team communication provides a prime access to the thinking and problem-solving routine of the teams when creativity is manifested (Stempfle \& Badke-Schaub, 2002). The third paradigm characterizes leadership as a facilitator for creativity where leadership communication is the main tool for motivation and inspiration. Leadership communication reflect individually centred communication between leader and subordinator with formal position power (Ruben \& Gigliotti, 2016; M. Mayfield \& J. Mayfield, 2017).

All of these perspectives are reflected in the analysis of co-occurrence of authors' keywords which was performed by searching the Web of Science (Clarivate Analytics) and collecting all appropriate research papers that provide insights into organizational creativity and organizational communication. According to this exploratory research, only a very small part of the papers $(\mathrm{N}=259)$ deals with the interplay between organizational creativity and organizational communication, thus showing that this topic is under-addressed. The categorization of research articles using VOSviewer (2018) software shows three interrelated clusters that represents tree levels of communication: corporate, team and leadership (see Figure 1).

The biggest (red) cluster represents papers of the first paradigm and reflects corporate level of analysis which is identified by keywords, such as knowledge management, design, organizational culture. Knowledge management and organizational culture are interlinked with two sub-topics - organizational communication and organizational creativity which shows corporate-level communication impact on creativity (Figure 1). The smallest cluster (blue) is denoted by team, innovation, culture and social networks. It identifies research papers written on the second paradigm and represents team level of communication. The third (green) cluster is represented by keywords as leadership, knowledge, and performance; it characterizes the last paradigm associated with leadership (leader-subordinate) level of communication. Next we will focus on the three dominant perspectives and present an overview of each in the following sub-sections.

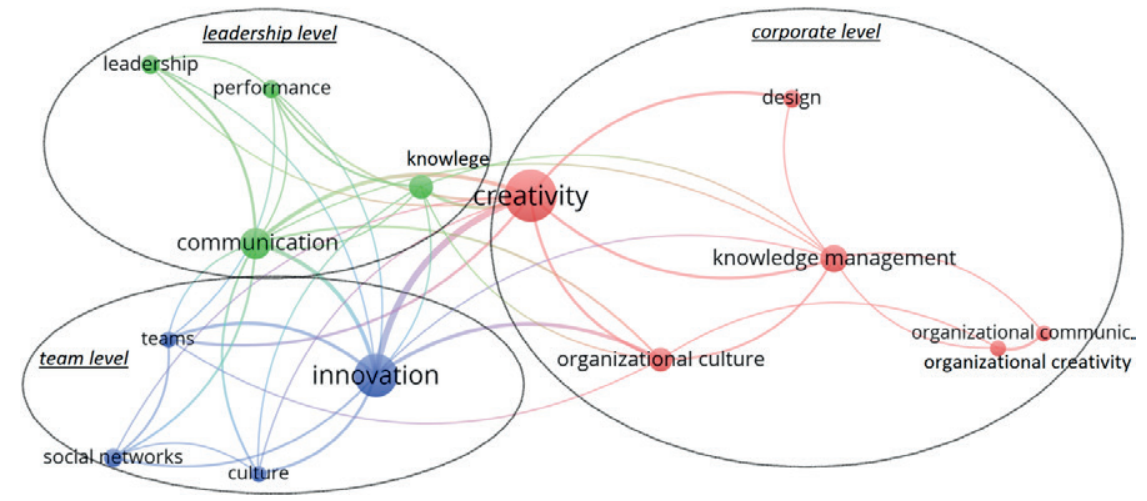

Figure 1. The categorization of research articles on organizational creativity and organizational communication using VOSviewer (source: created by authors) 


\subsection{Corporate level communication as a context for creativity}

We will give a brief overview of the articles that represent our first cluster and are identified by the keywords as organizational culture, knowledge management, and design. These articles focus on organizational creativity and analyse organizational culture as an environment in which the communicative process determines creativity (e.g. Linder \& Sperber, 2017). Since the focus is on disseminating knowledge, the articles analyse how it spreads in organizations through various communication techniques and formal channels (e.g. Ugnich, Chernokozov, \& Filinkova, 2017) and how internal corporate communication stimulates a positive context for creativity (Malhotra \& Ackfeldt, 2016). Accordingly, creating an organizational culture that is conducive to creativity is one of the most difficult challenges facing any organization, especially if it is dominated by rigour. Conversely, the use of alternative creative ways to address emerging issues is inherent in open-cultural organizations, supported by internal corporate communication. Organizational culture, as defined by Mikael Johnsson (2017, p. 84 ), is "the deepest level of basic values, assumptions and beliefs", which unites the members of the organization as well as determines their behaviour since it is also defined as a set of collective norms. When analysing the military as an organization, it should be noted that military culture is, in principle, unique and shaped by organizational structures, rules and norms. It is often presented in research as a culture of integration and unification (Redmond et al., 2015) and a strict hierarchical organization with prevailing authoritarianism. As noted by Milan Vego (2013, p. 84), "authoritarianism is a major obstacle to the creativity of both individuals and the military institution". Such organizational culture should restrict creativity, but this is not the case since the military trains and operates under high uncertainty where creative solutions are constantly needed. One of the most important factors of creativity in the military is communication that takes place in the exercise. This is best explained by Matthew Furtado (2017, p. 55) who analysed military decision-making: creativity in the military "occurs because collaboration allows individual planners access to distributed knowledge they do not possess" and its supported by rules, procedures and formal communication. To sum up, organizational culture is highly reflected by internal corporate communication which creates unique conditions for creativity to flourish.

\section{Team communication as a facilitator for creativity}

Communication in teams (Chen \& Agrawal, 2017), team-based learning (Ma \& Wu, 2017), networking (Donati, Zappalà, \& González-Romá, 2016) and group culture are the topics that predominate when examining how organizational communication affects organizational creativity. A team is perceived as an organization's cell where communication is a cornerstone for knowledge sharing and innovation (Kratzer, Gemünden, \& Lettl, 2008). Corporate innovations are perceived as a social activity in the teams where communication plays an important role (Mascia, Magnusson, \& Björk, 2015). Moreover, the support of team members, expressed through verbal and non-verbal communication, forms a sense of security, which is a prerequisite for creativity and innovation. According to Gail Fann Thomas, Roxanne Zolin and Jackie L. Hartman (2009), communication practices in teams form perceptions of 
the quality of information; accurate, timely and useful information creates trust and leads to higher performance of co-workers as creativity and innovation. Therefore, open communication based on trust is the basis for sharing knowledge in the organizations (Smaliukiené, Bekešienè, Chlivickas, \& Magyla, 2017). However, while analysing the relationship between the team and the organization, the authors identify a variety of communication barriers that interrupt the implementation of creative solutions. These are the routine and bureaucratic constraints, control, competition among teams, leading to knowledge hiding and distortion of information. One of the key determinants of creativity is the compatibility of team members' traits, which is high in a culture of uniformity (Baranski et al., 2007). In the military creativity manifests itself in teams where the team consistency dominates, with the norms oriented towards the result.

\section{Leadership communication as a motivator for creativity}

According to Zhang and Bartol (2010), leadership is a mediator between psychological empowerment and employee creativity; still, this relates more to individual rather than organizational creativity (Raelin, 2016). In addition, professionalism and autonomy neutralize the influence of leadership (Mumford \& Licuanan, 2004). However, in a rigid structure, the commander makes the most important decisions and sets the working conditions and, most importantly, as (Mumford, 2000) points out, provide[s] staff with the time that is necessary to think. Milton Mayfield and Jacqueline Mayfield (2017) in their study on leader motivating language found that leader's language encourages creativity in several ways. First, leaders show that employee's creativity is important for an organization, enable them to understand more clearly what resources (especially time) they have for creative problem solving. The leader, in this case, directs the creativity to implement the organization's vision. Equally important is the fact that leadership communication creates a zone of comfort where employees implement creative ideas.

\section{Theoretical model and measure development}

To sum up, we have developed a theoretical model where three interrelated levels of communication explain the expression of creativity in a rigid structure. Figure 2 provides a graphical representation of the expected relationship among creativity and the three levels of communication in an organization: corporate internal communication (Corg), team communication (Ctem) and leadership communication (Clead).

Creativity in an organization (CC) is a dependent variable in our theoretical model. Based on the framework of earlier research (Borghini, 2005; Auernhammer \& Hall, 2014), we understand the creativity as a process where co-workers are engaged in creative thinking (E1) and organization is producing new creative solutions (E2) (Figure 2).

Corg was measured using three positive indicators: (1) employees are motivated for exchanging ideas to solve problems creatively (CO1); (2) employees are encouraged to take part in decision making (CO2), (3) employees are informed about available finance and time resources for new creative solutions (CO3). 


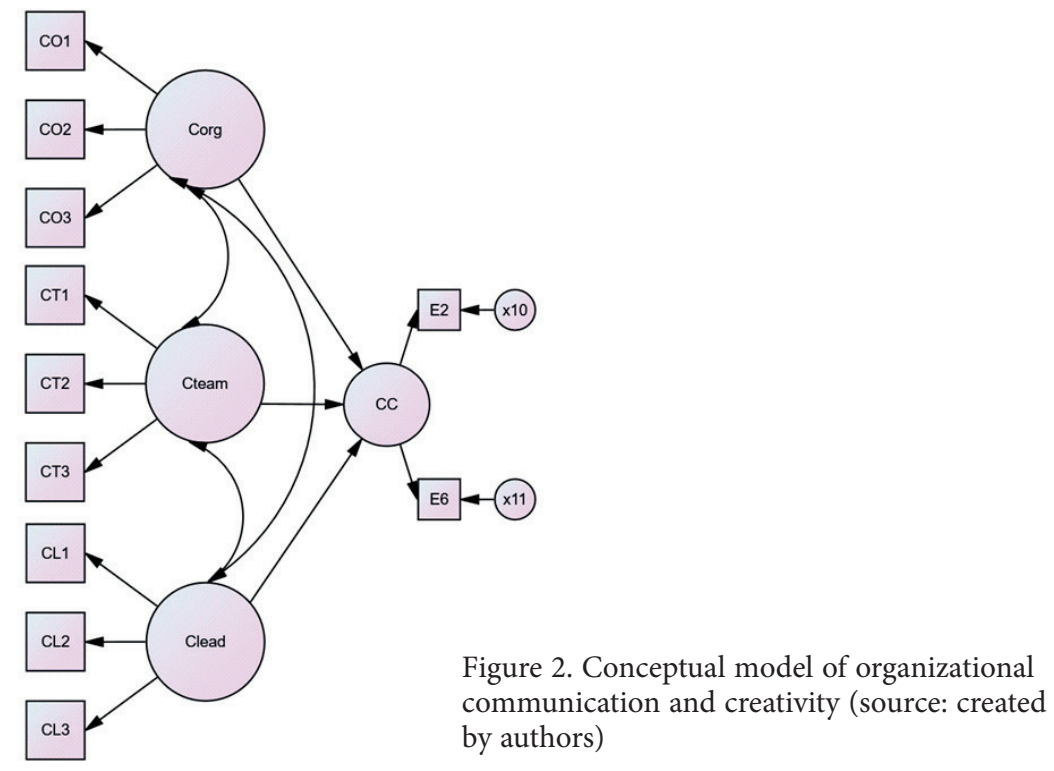

Ctem was measured using these indicators: (1) a team has established trusting and supportive relationships (CT1), (2) team members are encouraged to express their opinion (CT2), (3) idea recognition is related to individual position in the organization (indicator was recorded from negative to positive for the analysis) (CT3).

Clead represents not only personal style of leadership but also serves as a bridge between corporate goals and individual performance. Accordingly, this latent variable consists of these indicators: (1) leader shares an understanding of how to achieve goals (CL1), (2) leader creates the culture of trust (CL2), (3) leader provides feedback to those they lead (CL3).

\section{Method}

To measure the relationships between organizational creativity and organizational communication, data were collected via a survey. In all, 107 troops and civilian staff were selected from two functionally similar military units in Lithuanian Armed Forces. Respondents were asked to evaluate nine statements on a five-point Likert-type scale and to provide demographic information. The proportion of male to female participants was 4:1; the vast majority of respondents were 31-35 years old; nearly half of the respondents (44\%) had 11-15 years of work experience and only $1 \%$ of participants had less than 5 years. Of respondents, $71 \%$ had management experience and $24 \%$ of them were in leadership positions.

Structural equation model (SQM) test was used to test a theoretical network of relations among our observed and latent variables. The SQM was chosen to estimates the multiple and interrelated dependence in a single analysis of organizational communication and its impact towards creativity. The analysis of latent constructs and measurable variables of the theoretical causal model was based on path analysis, factor analysis, and linear regression (Byrne, 2016). In our case the model consisted of three exogenous variables (Corg, Cteam, Clead) and one endogenous variable creativity. The structural relationships are tested using IBM SPSS AMOS V25.0 program. 


\section{Results}

Before analysing the theoretical framework, the questionnaire is assessed to evaluate how the questions (variables) would reflect the latent factors. A principal components analysis was performed to investigate the factor structure of ach latent variable. All factors have an eigenvalue high enough to justify inclusion (Table 1). Additionally, we use Cronbach's alpha (CA) coefficient as it is most frequently used to test an internal consistency of a scale (Garson, 2012). CA in the research exceeds the minimum limit of 0.6 and indicates acceptable internal consistency of each group of measures.

Confirmatory factor analysis using the IBM SPSS AMOS V25.0 program is applied to test our theoretical (hypothesised) model by estimating how the observed variables are linked to latent factors. It also provided additional confirmation of construct validity of items and of constructs used in the main study. In this study, the latent factors associated with communication have three indicators each; a latent factor associated with creativity has two factors; in the initial stage 12 measurement error associated with factors and indicators are created, all together 16 distinct parameters are estimated.

Following the recommendation of James Jaccard and Choi K. Wan (1996), we use more than three fit test to demonstrate the appropriateness of proposed model. The literature (Byrne, 2016) recommends using chi-square $(\chi 2)$ with small and moderate samples, and we following this recommendation with our sample $\mathrm{N}=107$. The test of overall model fit results in a $\chi^{2}=66.316$ with 38 degrees of freedom and very low probability level ( $\mathrm{p}=$ 0.003). Moreover, the other indicators representing the goodness-of-fit of the theoretical

Table 1. The research construct and construct reliability (source: created by authors)

\begin{tabular}{|c|c|c|c|c|}
\hline Latent variables & Measurement indicators & Coding & $\begin{array}{c}\text { Factor } \\
\text { loading }\end{array}$ & $\begin{array}{c}\text { Cronbach's } \\
\text { alpha }\end{array}$ \\
\hline \multirow{2}{*}{$\begin{array}{l}\text { Organizational } \\
\text { creativity (CC) }\end{array}$} & Employees are engaged in creative thinking. & E1 & 0.805 & \\
\hline & Organization is producing new creative solutions & E2 & 0.805 & \\
\hline \multirow{3}{*}{$\begin{array}{l}\text { Corporate } \\
\text { internal } \\
\text { communication } \\
\text { (Corg) }\end{array}$} & $\begin{array}{l}\text { Employees are motivated for exchanging ideas to } \\
\text { solve problems creatively }\end{array}$ & $\mathrm{CO} 1$ & 0.755 & \multirow[t]{3}{*}{0.628} \\
\hline & $\begin{array}{l}\text { Employees are encouraged to participate in } \\
\text { decision making }\end{array}$ & $\mathrm{CO} 2$ & 0.734 & \\
\hline & $\begin{array}{l}\text { Employees are informed about available finance } \\
\text { and time resources for new creative solutions }\end{array}$ & $\mathrm{CO} 3$ & 0.797 & \\
\hline \multirow{3}{*}{$\begin{array}{l}\text { Team } \\
\text { communication } \\
\text { (Ctem) }\end{array}$} & $\begin{array}{l}\text { A team has established trusting and supportive } \\
\text { relationships }\end{array}$ & CT1 & 0.794 & \multirow[t]{3}{*}{0.684} \\
\hline & $\begin{array}{l}\text { Team members are encouraged to express their } \\
\text { opinion }\end{array}$ & CT2 & 0.829 & \\
\hline & $\begin{array}{l}\text { Idea recognition is related to individual position } \\
\text { (recoded to positive) }\end{array}$ & CT3 & 0.730 & \\
\hline \multirow{3}{*}{$\begin{array}{l}\text { Leadership } \\
\text { communication } \\
\text { (Clead) }\end{array}$} & $\begin{array}{l}\text { Leader shares an understanding of how to } \\
\text { achieve goals }\end{array}$ & CL1 & 0.884 & \multirow[t]{3}{*}{0.787} \\
\hline & Leader creates the culture of trust & CL2 & 0.811 & \\
\hline & Leader provides feedback to those they lead & CL3 & 0.818 & \\
\hline
\end{tabular}


model indicate mediocre to poor fit (Table 2); therefore, we introduced additional variables to the hypothesised model. These additional variables were based on the body of literature on organizational communication.

As it was already stated in our conceptual review, all three levels of communication are interconnected and at the same time supporting each other. This interconnection we identify as a covariance between Corg, Cteam and Clead in our respecified model. As structural equation modelling conjoins variance and measurement errors, we develop a respecified model (Saris \& Revilla, 2016). In the theoretical model variables and measurement errors are random, whereas in the respecified model they are interconnected. Following methodological guidelines of structural equation modelling to "add only one parameter at a time to the model" (Byrne, 2016, p. 132), using goodness-to-fit statistics and the modification indices for each parameter, we estimated covariance within measurement errors of team communication $(\mathrm{x} 5 \leftrightarrow \mathrm{x} 6)$ and between indicators of corporate communication and team communications ( $\mathrm{x} 2 \leftrightarrow \mathrm{x} 6)$ as well as of team communication and leadership communication $(x 4 \leftrightarrow x 9 ; x 6 \leftrightarrow x 9 ; x 6 \leftrightarrow x 8)$.

The respecified model is evaluated by statistical means to determine the adequacy of its goodness-of-fit. The overall model fit is acceptable, as can be seen from Table 2. The test results $\chi 2=46.536$ with 33 degrees of freedom and probability level 0.059 . Other, more pragmatic goodness-of-fit indicators also show moderate to good fit. Root mean square error of approximation $(\mathrm{RMSEA}=0.061)$ is calculated as the most informative criteria in model measurement and it indicated moderate fit. The root mean square residual $(\mathrm{RMR}=0.061)$ represents the average value across all standardized residuals and in our case indicates wellfitting model. As of small sample, one of the most used fit indices normed fit index (NFI = $0.872)$ is extended by comparative fit index $(\mathrm{CFI}=9.56)$. Value NFI is near to 0.90 indicates mediocre fit whereas CFI is $>0.90$ which takes sample size into account represents a wellfitting model. In summarizing goodness-of fit statistic for theoretical hypothesised model reflects a mediocre to well-fitting model.

Respecified four-factor model demonstrate reliability and factor stability. Table 3 shows the results of the confirmatory factor analysis (CFA) test and Figure 3 visualizes the relationships of variables in the structural model. Based on the results, Cteam is the strongest predictor of organizational creativity $(\beta=1.654, \mathrm{p}=0.415)$. It exceeds the leadership communication marginally $(\beta=1.198 ; \mathrm{p}=0.190)$ and corporate communication significantly $(\beta=0.682$; $\mathrm{p}=0.233$ ). All together three levels of communication create a statistically significant impact

Table 2. Goodness-of-fit statistics of the hypothesised and respecified models (source: created by authors)

\begin{tabular}{|c|c|c|c|}
\hline Fit index & Recommended value & Hypothesised model & Respecified model \\
\hline$\chi^{2 / \mathrm{df}}$ & $\leq 3$ & 1.745 & 1.410 \\
\hline Probability level & $>0.05$ & 0.003 & 0.059 \\
\hline RMSEA & $\leq 0.08$ & 0.082 & 0.061 \\
\hline RMR & $\leq 0.05$ & 0.713 & 0.613 \\
\hline NFI & $\geq 0.9$ & 0.817 & 0.872 \\
\hline CFI & $\geq 0.9$ & 0.908 & 0.956 \\
\hline TLI & $\geq 0.9$ & 0.867 & 0.927 \\
\hline
\end{tabular}


on creativity in an organization. Along with these results, this study indicates specific interrelationship between team communication and other levels of communication in organization: covariance between these latent indicators are negative in the model (Figure 3) and correlations indicates strong negative relationship (Table 4).

Table 3. Respecified four-factor model: parameter estimates (source: created by authors)

\begin{tabular}{|c|c|c|c|c|c|c|}
\hline \multicolumn{3}{|c|}{ Relationship } & Estimate & S.E. & C.R. & P \\
\hline CC & $<---$ & Corg & 0.682 & 0.572 & 1.192 & 0.233 \\
\hline CC & $<---$ & Cteam & 1.654 & 2.029 & 0.816 & 0.415 \\
\hline CC & $<---$ & Clead & 1.198 & 0.915 & 1.310 & 0.190 \\
\hline CO3 & $<---$ & Corg & 1.000 & & & \\
\hline CO2 & $<---$ & Corg & 1.058 & 0.274 & 3.859 & ${ }^{* * *}$ \\
\hline CO1 & $<---$ & Corg & 1.017 & 0.252 & 4.031 & ${ }^{* * *}$ \\
\hline CT3 & $<---$ & Cteam & 1.000 & & & \\
\hline CT2 & $<---$ & Cteam & 0.917 & 0.262 & 3.493 & ${ }^{* * *}$ \\
\hline CT1 & $<---$ & Cteam & 1.340 & 0.293 & 4.574 & ${ }^{* * *}$ \\
\hline CT3 & $<---$ & Clead & 1.000 & & & \\
\hline CT2 & $<---$ & Clead & 0.959 & 0.145 & 6.634 & ${ }^{* * *}$ \\
\hline CT1 & $<---$ & Clead & 1.232 & 0.168 & 7.313 & ${ }^{* * *}$ \\
\hline E1 & $<---$ & CC & 1.000 & & & \\
\hline E2 & $<---$ & CC & 1.033 & 0.266 & 3.881 & ${ }^{* * *}$ \\
\hline
\end{tabular}

*** Significant at the $1 \%$ level.

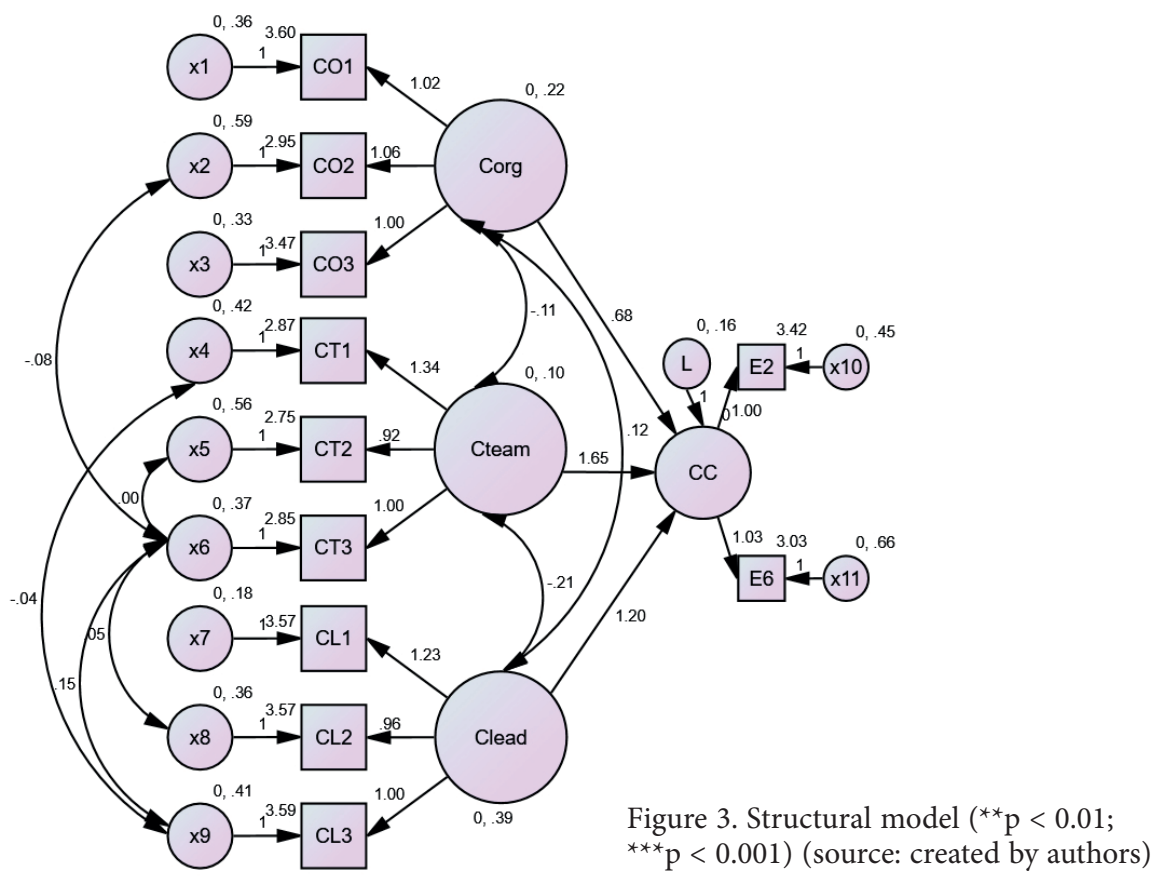


Table 4. Correlations between latent variables of communication in respecified model (source: created by authors)

\begin{tabular}{|c|c|c|c|}
\hline Clead & $<-->$ & Corg & .420 \\
\hline Clead & $<-->$ & Cteam & -1.068 \\
\hline Corg & $<-->$ & Cteam & -.758 \\
\hline
\end{tabular}

\section{Conclusions and discussions}

The study shows that communication has a significant direct impact on organizational creativity in rigid structures. This finding is aligned with the insights from previous analysis of non-military organizations (e.g. Ruppel \& Harrington, 2000) where multilayer communication was found to result greater commitment to creativity. According to or study, all three levels of communication, i.e. corporate, team and leadership, are important for the development of creativity but on a different degree. Thus, the results of the study have important implications for both practical and theoretical development.

The first implication is related to the entire system of internal communication in an organization. According to the results, all three levels of communication make a strong positive impact to the organization creativity; therefore, greater emphasis should be placed on the compatibility of information between the levels. Moreover, the results show strong interconnection between communication levels. In rigid structures, communicative messages relayed on these levels and reinforce its impact towards creativity. This is an interesting theoretical result proving that the isolation of communication levels in the research is unreasonable. Our results indicate that when analysing tem communication, it is necessary to analyse it together with internal corporate communication and leadership communication and vice versa since the separate analysis of team communication is not expedient.

The second implication is related to a negative interconnection between team communication and other levels of communication. Corporate internal communication and Corp weakens team communication and vice versa. This negative interconnection can be explained by the nature of team development. As it was found in previous studies on team development, a team (and team communication) becomes week in highly centralized organizations (Wang, Tjosvold, Chen, \& Luo, 2014) and with autocratic leaders (Srivastava, Bartol, \& Locke, 2006). This is also true vice versa: team professionalism and autonomy neutralize the influence of leadership and decrease the demand for corporate coherence. Taking this perspective into account, it can be concluded that the weaker team communication is, the bigger need is for strong corporate and leadership communication in developing creative solutions.

Thirdly, acknowledging the importance of the team role for organizational creativity, it is important for the team to have effective communication. The results of this study suggest that team communication, which is dominated by trust, encouragement and recognition create a favourable environment for organizational creativity. At the same time these the elements of team communication do not occur in isolation. They are interconnected with corporate communication and leadership communication. These results confirms the findings of the previous studies (e.g. Omilion-Hodges \& Ackerman, 2018) that team communication is not determined solely by the team itself. Hence, co-workers should be encouraged to commu- 
nicate and develop their own social network within the organization in order to engage in more fluid and creative social interactions. Managers at all levels of organizations have this responsibility and they must ensure a favourable environment for this to happen. Therefore, management in general is very important in ensuring team communication.

It should be noted, however, that the study had several limitations. This is primarily due to the choice of variables. The model can explain only a handful of variables in organizational communication, so other variables remain unexplored. In our case, we looked at the most frequently analysed variables of organizational communication which we chose using author keywords analysis. Future studies could look at a greater number of variables that would determine which variables of communication have the greatest impact on organizational creativity. Another restriction concerns data. We only used the self-report survey, so it could have slightly changed the size of correlations between measures. It would be relevant if, in the future, the results of this study were compared to the results of a study of a different nature.

\section{References}

Anderson, N., Potočnik, K., \& Zhou, J. (2014). Innovation and creativity in organizations: a state-of-thescience review, prospective commentary, and guiding framework. Journal of Management, 40(5), 1297 1333. https://doi.org/10.1177/0149206314527128

Auernhammer, J., \& Hall, H. (2014). Organizational culture in knowledge creation, creativity and innovation: towards the Freiraum model. Journal of Information Science, 40(2), 154-166. https://doi.org/10.1177/0165551513508356

Baranski, J. V., Thompson, M. M., Lichacz, F. M. J., McCann, C., Gil, V., Pastò, L., \& Pigeau, R. A. (2007). Effects of sleep loss on team decision making: motivational loss or motivational gain? Human Factors: The Journal of the Human Factors and Ergonomics Society, 49(4), 646-660. https://doi.org/10.1518/001872007X215728

Boies, K., Fiset, J., \& Gill, H. (2015). Communication and trust are key: unlocking the relationship between leadership and team performance and creativity. The Leadership Quarterly, 26(6), 1080-1094. https://doi.org/10.1016/j.leaqua.2015.07.007

Borghini, S. (2005). Organizational creativity: breaking equilibrium and order to innovate. Journal of Knowledge Management, 9(4), 19-33. https://doi.org/10.1108/13673270510610305

Byrne, B. M. (2016). Structural equation modeling with AMOS: basic concepts, applications, and programming. Series: Multivariate Applications Series. New York, London: Routledge.

Chen, M.-H., \& Agrawal, S. (2017). Do communication barriers in student teams impede creative behavior in the long run? - a time-lagged perspective. Thinking Skills and Creativity, 26, 154-167. https://doi.org/10.1016/j.tsc.2017.10.008

Cooren, F., Kuhn, T., Cornelissen, J. P., \& Clark, T. (2011). Communication, organizing and organization: an overview and introduction to the special issue. Organization Studies, 32(9), 1149-1170. https://doi.org/10.1177/0170840611410836

Donati, S., Zappalà, S., \& González-Romá, V. (2016). The influence of friendship and communication network density on individual innovative behaviours: a multilevel study. European Journal of Work and Organizational Psychology, 25(4), 583-596. https://doi.org/10.1080/1359432X.2016.1179285

Duncan, H. D. (2002). Communication and social order. New Brunswick, London: Transaction Publishers.

Fann Thomas, G., Zolin, R., \& Hartman, J. L. (2009). The central role of communication in developing trust and its effect on employee involvement. Journal of Business Communication, 46(3), 287-310. https://doi.org/10.1177/0021943609333522 
Furtado, M. (2017). Creativity in complex military systems. Fort Leavenworth: School for Advanced Military Studies, United States Army Command and General Staff College.

Garson, G. D. (2012). Testing statistical assumptions. Series: Blue Book Series. Asheboro, NC: Statistical Associates Publishing.

Jaccard, J., \& Wan, Ch. K. (1996). LISREL approaches to interaction effects in multiple regression. Series: Quantitative Applications in the Social Sciences. M. S. Lewis-Beck (Series Ed.). Vol. 114. Thousand Oaks, CA: SAGE Publications, Inc. https://doi.org/10.4135/9781412984782

Johnsson, M. (2017). Innovation enablers for innovation teams - a review. Journal of Innovation Management, 5(3), 75-121.

Kratzer, J., Gemünden, H. G., \& Lettl, Ch. (2008). Balancing creativity and time efficiency in multi-team R\&D projects: the alignment of formal and informal networks. R\&D Management, 38(5), 538-549. https://doi.org/10.1111/j.1467-9310.2008.00528.x

Linder, Ch., \& Sperber, S. (2017). If what you want is not what you get: a communication-based approach to top managers' intended firm creativity and employees' failure to deliver. European Management Review, 14(3), 227-246. https://doi.org/10.1111/emre.12104

Ma, J., \& Wu, Zh. (2017). A study on team-based learning based on WeChat public platform: the case of design and implementation of Mass Media Management course. Eurasia Journal of Mathematics, Science and Technology Education, 13(11), 7307-7312. https://doi.org/10.12973/ejmste/79602

Malhotra, N., \& Ackfeldt, A.-L. (2016). Internal communication and prosocial service behaviors of front-line employees: investigating mediating mechanisms. Journal of Business Research, 69(10), 4132-4139. https://doi.org/10.1016/j.jbusres.2016.03.038

Mascia, D., Magnusson, M., \& Björk, J. (2015). The role of social networks in organizing ideation, creativity and innovation: an introduction. Creativity and Innovation Management, 24(1), 102-108. https://doi.org/10.1111/caim.12111

Mayfield, M., \& Mayfield, J. (2017). Leader talk and the creative spark: a research note on how leader motivating language use influences follower creative environment perceptions. International Journal of Business Communication, 54(2), 210-225. https://doi.org/10.1177/2329488416687057

Mumford, M. D. (2000). Managing creative people: strategies and tactics for innovation. Human Resource Management Review, 10(3), 313-351. https://doi.org/10.1016/S1053-4822(99)00043-1

Mumford, M. D., \& Licuanan, B. (2004). Leading for innovation: conclusions, issues, and directions. The Leadership Quarterly, 15(1), 163-171. https://doi.org/10.1016/j.leaqua.2003.12.010

Negus, K., \& Pickering, M. (2004). Creativity, communication and cultural value. London, Thousand Oaks, New Delhi: SAGE Publications.

Omilion-Hodges, L. M., \& Ackerman, C. D. (2018). From the technical know-how to the free flow of ideas: exploring the effects of leader, peer, and team communication on employee creativity. Communication Quarterly, 66(1), 38-57. https://doi.org/10.1080/01463373.2017.1325385

Raelin, J. A. (2016). Imagine there are no leaders: reframing leadership as collaborative agency. Leadership, 12(2), 131-158. https://doi.org/10.1177/1742715014558076

Redmond, S. A., Wilcox, S. L., Campbell, S., Kim, A., Finney, K., Barr, K., \& Hassan, A. M. (2015). A brief introduction to the military workplace culture. Work, 50(1), 9-20.

Ruler, van B., \& Lange, de R. (2003). Barriers to communication management in the executive suite. Public Relations Review, 29(2), 145-158. https://doi.org/10.1016/S0363-8111(03)00017-1

Ruben, B. D., \& Gigliotti, R. A. (2016). Leadership as social influence: an expanded view of leadership communication theory and practice. Journal of Leadership \& Organizational Studies, 23(4), 467-479. https://doi.org/10.1177/1548051816641876

Ruppel, C. P., \& Harrington, S. J. (2000). The relationship of communication, ethical work climate, and trust to commitment and innovation. Journal of Business Ethics, 25(4), 313-328.

https://doi.org/10.1023/A:1006290432594 
Sadia, A., Mohd Salleh, B., Abdul Kadir, Z., \& Sanif, S. (2016). The relationship between organizational communication and employees productivity with new dimensions of effective communication flow. Journal of Business and Social Review in Emerging Economies, 2(2), 93-100. https://doi.org/10.26710/jbsee.v2i2.35

Saintilan, P., \& Schreiber, D. (2017). Managing organizations in the creative economy: organizational behaviour for the cultural sector. Series: Mastering Management in the Creative and Cultural Industries. London: Routledge. https://doi.org/10.4324/9781315645032

Saris, W. E., \& Revilla, M. (2016). Correction for measurement errors in survey research: necessary and possible. Social Indicators Research, 127(3), 1005-1020. https://doi.org/10.1007/s11205-015-1002-x

Smaliukienė, R., Bekešiene, S., Chlivickas, E., \& Magyla, M. (2017). Explicating the role of trust in knowledge sharing: a structural equation model test. Journal of Business Economics and Management, 18(4), 758-778. https://doi.org/10.3846/16111699.2017.1317019

Srivastava, A., Bartol, K. M., \& Locke, E. A. (2006). Empowering leadership in management teams: effects on knowledge sharing, efficacy, and performance. Academy of Management Journal, 49(6), 1239-1251. https://doi.org/10.5465/amj.2006.23478718

Stempfle, J., \& Badke-Schaub, P. (2002). Thinking in design teams - an analysis of team communication. Design Studies, 23(5), 473-496. https://doi.org/10.1016/S0142-694X(02)00004-2

Ugnich, E., Chernokozov, A., \& Filinkova, E. (2017). Problem of knowledge generation in terms of university innovation ecosystem development. In Proceedings of the 7th International Scientific and Practical Conference "Current Issues of Linguistics and Didactics: The Interdisciplinary Approach in Humanities" (CILDIAH 2017). Advances in Social Science, Education and Humanities Research, 97, 307-312.

Vego, M. (2013). On military creativity. Joint Force Quarterly, 70(3), 83-90.

VOSviewer. (2018). VOSviewer version 1.6.7. Retrieved from http://www.vosviewer.com/

Wang, Zh., Tjosvold, D., Chen, Y., \& Luo, Zh. (2014). Cooperative goals and team performance: examining the effects of advice network. Asia Pacific Journal of Management, 31(3), 835-852.

https://doi.org/10.1007/s10490-014-9382-z

Woodman, R. W., Sawyer, J. E., \& Griffin, R. W. (1993). Toward a theory of organizational creativity. The Academy of Management Review, 18(2), 293-321. https://doi.org/10.5465/amr.1993.3997517

Zhang, X., \& Bartol, K. M. (2010). The influence of creative process engagement on employee creative performance and overall job performance: a curvilinear assessment. Journal of Applied Psychology, 95(5), 862-873. https://doi.org/10.1037/a0020173

\title{
ORGANIZACINĖS KOMUNIKACIJOS IR KÜRYBIŠKUMO SANTYKIS: KAIP JIS PLĖTOJAMAS UŽDAROSE STRUKTÜROSE?
}

\author{
Rasa SMALIUKIENĖ, Antanas SURVILAS
}

\begin{abstract}
Santrauka
Vis daugiau mokslininkų kūrybišką elgesị analizuoja sudètingose socialinèse sistemose ir atsisako siauro požiūrio ị individo kūrybiškumą; kartu kūrybiškumas darbo vietoje, t. y. aplinkoje, kurioje jis gimsta, yra mažai nagrinejjamas. Kūrybiškumas, kaip organizacijos fenomenas, uždarose organizacinèse struktūrose nèra tiriamas apskritai. Kad būtų užpildyta ši mokslo žinių spraga, organizacinis kūrybiškumas šiame straipsnyje analizuojamas kariuomenès kontekste. Straipsnyje tiriama organizacinè komunikacija ir jos poveikis kūrybiškumui. Organizacinẻ komunikaci-
\end{abstract}


ja tyrime išskaidoma ị tris lygmenis: korporacinį, komandos ir vadovo-pavaldinio. Straipsnyje nagrinejjami du klausimai: 1) kaip komunikacija yra susijusi su kūrybiškumu; 2) kaip komunikacija skirtingais lygmenimis prisideda prie organizacinio kūrybiškumo uždarose hierarchinèse struktūrose. Atsakant $\mathfrak{i}$ šiuos klausimus buvo sukurtas teorinis daugiafaktoris modelis, kuris empiriškai patikrintas naudojant $A M O S$ programą. Remiantis empiriniais duomenimis, buvo pasiūlytas trijų lygių organizacinès komunikacijos modelis, skirtas kūrybiškumui skatinti uždarose organizacinèse struktūrose.

Reikšminiai žodžiai: korporacinè komunikacija, komunikacija tarp vadovo ir pavaldinio, kariuomene, organizacinè komunikacija, organizacinis kūrybiškumas, komunikacija grupeje. 